Jurnal Ners Indonesia, Vol.10 No.1, September 2019

\title{
EFEKTIVITAS KOMPRES ALOE VERA TERHADAP NYERI PEMBENGKAKAN PAYUDARA PADA IBU MENYUSUI
}

\author{
Ratih Indah Sari ${ }^{1}$, Yulia Irvani Dewi ${ }^{2}$, Ganis Indriati ${ }^{3}$ \\ ${ }^{1,2,3}$ Fakultas Keperawatan Universitas Riau Jalan Pattimura No 9 Gedung G Pekanbaru Riau \\ Kode Pos 28131 Indonesia \\ Email: ratihindahsari487@gmail.com
}

\begin{abstract}
Abstrak
Pembengkakan payudara merupakan salah satu masalah menyusui yang sering dialami oleh ibu setelah melahirkan. Pembengkakan payudara dapat menimbulkan rasa nyeri yang berdampak pada proses pemberian ASI. Penelitian ini bertujuan untuk mengetahui efektivitas kompres aloe vera terhadap nyeri pembengkakan payudara ibu menyusui di wilayah kerja Puskesmas Harapan Raya Pekanbaru. Penelitian ini menggunakan desain quasi-eksperimen dengan rancangan non-randomized pretest-posttest control group. Teknik pengambilan sampel menggunakan teknik accidental sampling dengan jumlah responden sebanyak 34 orang responden. Alat ukur yang digunakan adalah Numeric Rating Scale (NRS). Analisa statistik menggunakan uji dependent $t$-test dan independent $t$-test. Hasil analisa univariat diperoleh mayoritas umur responden 20-35 tahun sebanyak 25 orang $(73,5 \%)$, paritas multipara sebanyak 20 orang $(58,8 \%)$, pendidikan terakhir mayoritas SMA yaitu 16 orang $(47,1 \%)$, dan jenis persalinan mayoritas normal sebanyak 24 orang $(70,6 \%)$. Rata-rata intensitas nyeri kelompok eksperimen pre test 5,7059 dan post test 2,7059 dengan perbedaan 3,00000, sedangkan kelompok kontrol pre test 5, 0588 dan post test 4,5294 dengan perbedaan 0,52941. Hasil analisis statistik menunjukkan bahwa $p$ value $=0,000<\alpha(0,05)$, sehingga didapatkan bahwa kompres aloe vera efektif menurunkan intensitas nyeri pembengkakan payudara ibu menyusui. Kompres aloe vera dapat direkomendasikan sebagai terapi komplementer dengan nyeri pembengkakan payudara.
\end{abstract}

Kata kunci: kompres aloe vera, menyusui, nyeri pembengkakan payudara

\begin{abstract}
Breast engorgement is one of breastfeeding problem that was often experienced by mothers after postpartum period. Breast engorgement may caused breast pain which affect breastfeeding process. The purpose of this research is to know the effectiveness of aloe vera compress against breast engorgement pain on breastfeeding mothers in Harapan Raya Health Center working area. The method used quasy-experiment with a non-randomized pretest-posttest control group. The sampling technique use accidental sampling with the amount 34 respondents. The instrument used was pain intensity observation sheet with numeric rating scale (NRS). The analyses utilized were univariate and bivariate analyses using dependent t-test and independent t-test. Applying univariate analysis to determine the frequency distribution of respondent characteristic, the result obtained that 25 mothers (73,5\%) aged between 20-35 years, majority of parity is multipara as many as 20 mothers (58,8\%), and 16 mothers (47,1\%) were senior high school graduated, and majority type of normal childbirth is a 24 mothers (70,6\%). Average pain intensity on intervention group pre test 5,7059 and post test 2,7059 with difference 3,00000, while the control group pre test 5,0588 and post test 4,5294 with difference 0,52941. The results of statistical analysis showed $p$ value $=0,000<\alpha(0,05)$, it shows that aloe vera compress is effective to reduce the intensity of breast engorgement pain on breastfeeding mothers. Aloe vera compress could be a recommended alternative for complementary therapies to reduce breast engorgement pain.
\end{abstract}

Keywords: aloe vera compress, breast engorgement pain, breastfeeding

\section{PENDAHULUAN}

Keberhasilan proses menyusui dimulai dengan Inisiasi Menyusui Dini (IMD). Data UNICEF dan WHO (2018) mengatakan bahwa tingkat cakupan IMD di dunia adalah $42 \%$. Proporsi ibu nifas yang melakukan IMD di Indonesia yaitu sebesar 58,2\%, sedangkan yang tidak melakukan IMD sebesar $41,8 \%$ 
Ratih Indah Sari ${ }^{1}$, Yulia Irvani Dewi ${ }^{2}$, Ganis Indriati ${ }^{3}$, Efektivitas Kompres Aloe Vera terhadap Nyeri Pembengkakan Payudara pada Ibu Menyusui

(Riskesdas, 2018). Hal ini menunjukkan bahwa program IMD di Indonesia belum sepenuhnya dilaksanakan dan berbagai masalah menyusui bisa saja menjadi penyebabnya.

Masalah menyusui yang sering terjadi adalah masalah pada puting seperti puting terbenam, puting lecet, puting melesak atau puting masuk kedalam. Masalah lainnya adalah pembengkakan payudara, infeksi payudara, ASI yang sedikit, teknik menyusui yang salah, dan tidak sering menyusui. Prevalensi masalah menyusui sangat tinggi dengan insiden kejadian pembengkakan payudara didunia adalah 1:8000 (John, Cordeiro, Manjima, Gopinath, \& Tamrakar, 2015).

Data terbaru WHO tahun 2015 di Amerika Serikat, persentase perempuan menyusui yang mengalami pembengkakan payudara rata-rata mencapai $87,05 \%$ atau sebanyak 8242 ibu nifas dari 12.765 orang (WHO, 2015; Meihartati, 2017). Data dari Depkes RI (2012) menunjukkan angka pembengkakan payudara di Indonesia berdasarkan penelitian terbanyak ditemukan pada ibu-ibu bekerja yaitu sebanyak $16 \%$ dari ibu yang menyusui (Depkes RI, 2012; Yanti, 2017). Selain itu pembengkakan payudara terjadi 253 kali (48\%) lebih tinggi pada primipara (Keila, Telma, \& Claudia, 2009; Zuhana, 2017).

Pembengkakan payudara merupakan kondisi fisiologis yang tidak menyenangkan ditandai dengan bengkak dan nyeri pada payudara yang terjadi karena peningkatan volume ASI, dan kongesti limfatik serta vaskular (Thomas, Chhugani, \& Thokchom, 2017). Pembengkakan payudara disebabkan karena keterlambatan dalam menyusui dini, ASI yang kurang sering dikeluarkan serta adanya batasan waktu saat menyusui (Wahyuni, 2018). Pembengkakan payudara menimbulkan nyeri payudara.

Manna, Podder dan Devi (2016) menyatakan bahwa nyeri yang dirasakan ibu menyusui dengan pembengakakan rata-rata dengan skala nyeri berat (6-8) dan skala nyeri sedang (3-5). Nyeri payudara terjadi karena peningkatan aliran vena dan limfe akibat penyempitan duktus laktiferi atau oleh kelenjar-kelenjar yang tidak dikosongkan dengan sempurna (Meihartati, 2017). Pembengkakan payudara jika tidak ditangani dengan segera dapat menimbulkan masalah baru yaitu mastitis dan bahkan abses payudara (Indahsari \& Chotimah, 2017).

Pembengkakan payudara juga menyebabkan ibu menghentikan proses menyusui karena payudara terasa sakit, tidak nyaman saat menyusui, dan mengganggap jika payudara bermasalah maka proses menyusui dihentikan agar tidak menularkan penyakit kepada anaknya (Apriani, Wijayanti, \& Widyastutik, 2018). Hal ini dapat memberikan dampak terhadap pemberian ASI eksklusif pada bayi, jika bayi tidak mendapatkan ASI maka kebutuhan gizi bayi 
Jurnal Ners Indonesia, Vol.10 No.1, September 2019

tidak terpenuhi secara baik dan bayi akan mudah terkena penyakit (Alhadar \& Umaternate, 2017).

Salah satu tanaman yang memiliki khasiat obat adalah aloe vera. Sushen et al (2017) menyatakan bahwa aloe vera dapat digunakan untuk mengatasi nyeri payudara karena menstruasi atau nyeri payudara akibat proses memberhentikan ASI. Aloe vera memiliki kandungan anthraquinone yang mengandung aloin dan emodin yang dapat berfungsi sebagai analgesik (Surya, Gouri, Yogeshchand, Gyanander, Jitender, \& Garg, 2015). Aktivitas analgesik pada aloe vera juga dihubungkan dengan adanya enzim carboxypeptidase dan bradykinase yang dapat mengurangi rasa sakit. Pengurangan rasa sakit terjadi melalui stimulasi sistem kekebalan tubuh dan penurunan prostaglandin yang bertanggung jawab untuk rasa sakit (Mwale \& Masika, 2010).

Hasil studi pendahuluan yang dilakukan pada bulan Oktober 2018 di wilayah kerja Puskesmas Harapan Raya didapatkan data ibu bersalin sebanyak 1.363 orang. Peneliti juga melakukan wawancara dengan 10 orang ibu menyusui dan diperoleh data sebanyak 5 orang ibu menyusui pernah mengalami nyeri pembengkakan payudara, 2 orang ibu postpatum hari ke-4 mengatakan bahwa payudaranya terasa bengkak dan nyeri, dan 3 orang ibu menyusui tidak mengalami nyeri pembengkakan payudara. Ibu menyusui yang mengalami pembengkakan payudara mengatakan bahwa mereka tidak memberikan
ASI kepada bayinya sejak hari pertama post partum karena ASI yang tidak dapat dikeluarkan atau karena merasakan nyeri payudara saat menyusui.

Nyeri pembengkakan payudara yang tidak ditindak lanjuti dapat menimbulkan komplikasi lebih lanjut, sehingga diperlukan penatalaksanaan yang efektif untuk mengatasi nyeri pembengkakan payudara pada ibu menyusui. Peneliti, berdasarkan permasalahan tersebut tertarik untuk meneliti tentang efektivitas kompres aloe vera terhadap nyeri pembengkakan payudara pada ibu menyusui.

\section{METODE PENELITIAN}

Penelitian ini dilaksanakan diwilayah kerja Puskesmas Harapan Raya. Desain penelitian adalah quasy experiment dengan rancangan non equivalent control group. Pengambilan sampel menggunakan teknik accidental sampling. Populasi dalam penelitian ini adalah seluruh ibu menyusui yang berada diwilayah kerja Puskesmas Harapan Raya, Klinik Bersalin Taman Sari, Klinik Pratama Putri Asih, dan BPS Yesmita Nora, Amd. Keb, dengan jumlah responden sebanyak 34 orang, 17 responden yang pertama dijumpai menjadi kelompok eksperimen dan 17 responden selanjutnya adalah kelompok kontrol. Sampel memenuhi kriteria inklusi yaitu ibu menyusui yang mengalami nyeri pembengkakan payudara dengan skala nyeri minimal 2.

Penelitian sebelum dilakukan telah lolos kaji etik oleh komite etik penelitian kesehatan 
Ratih Indah Sari ${ }^{1}$, Yulia Irvani Dewi ${ }^{2}$, Ganis Indriati ${ }^{3}$, Efektivitas Kompres Aloe Vera terhadap Nyeri Pembengkakan Payudara pada Ibu Menyusui

STIKes Hang Tuah Pekanbaru dengan nomor 026/KEPK/STIKes-HTP/V/2019.

Pengumpulan data menggunakan lembar observasi Numeric Rating Scale (NRS) untuk mengetahui intensitas nyeri sebelum dan sesudah dilakukanya intervensi kompres aloe vera. Analisis data menggunakan analisis univariat dan bivariat. Analisis statitistik menggunkan uji beda dua mean dependent sample T test dan independent $T$ test.

\section{HASIL PENELITIAN}

\section{A. Analisis Univariat}

1. Karakteristik Responden

Tabel 1

Gambaran distribusi karakteristik responden meliputi usia, paritas, pendidikan terakhir, dan jenis persalinan.

\begin{tabular}{|c|c|c|c|c|c|c|c|}
\hline \multirow[t]{2}{*}{ Karakteristik } & \multicolumn{2}{|c|}{$\begin{array}{l}\text { Kelompok Eksperimen } \\
(n=17)\end{array}$} & \multicolumn{2}{|c|}{$\begin{array}{l}\text { Kelompok Kontrol } \\
(n=17)\end{array}$} & \multicolumn{2}{|c|}{ Jumlah } & \multirow[t]{2}{*}{ P value } \\
\hline & $\mathbf{n}$ & $\%$ & $\mathbf{n}$ & $\%$ & $\mathbf{n}$ & $\%$ & \\
\hline \multicolumn{8}{|l|}{ Usia } \\
\hline a. $<20$ tahun & 2 & 11,8 & 0 & 0 & 2 & 5,9 & \multirow{3}{*}{0,131} \\
\hline b. 20-35 tahun & 13 & 76,5 & 12 & 70,6 & 25 & 73,5 & \\
\hline c. $>35$ tahun & 2 & 11,8 & 5 & 29,4 & 7 & 20,6 & \\
\hline Total & 17 & 100 & 17 & 100 & 34 & 100 & \\
\hline \multicolumn{8}{|l|}{ Paritas } \\
\hline a. Primipara & 8 & 47,1 & 4 & 23,5 & 12 & 35,3 & \multirow{3}{*}{0,113} \\
\hline b. Multipara & 8 & 47,1 & 12 & 70,6 & 20 & 58,8 & \\
\hline c. Grandemultipara & 1 & 5,9 & 1 & 5,9 & 2 & 5,9 & \\
\hline Total & 17 & 100 & 17 & 100 & 34 & 100 & \\
\hline \multicolumn{8}{|l|}{ Pendidikan Terakhir } \\
\hline a. SD & 2 & 11,8 & 3 & 17,6 & 5 & 14,7 & \multirow{4}{*}{0,175} \\
\hline b. SMP & 1 & 5,9 & 5 & 29,4 & 6 & 17,6 & \\
\hline c. SMA & 10 & 58,8 & 6 & 35,3 & 16 & 47,1 & \\
\hline d. PT & 4 & 23,5 & 3 & 17,6 & 7 & 20,6 & \\
\hline Total & 17 & 100 & 17 & 100 & 34 & 100 & \\
\hline \multicolumn{8}{|l|}{ Jenis Persalinan } \\
\hline a. Normal & 13 & 76,5 & 11 & 64,7 & 24 & 70,6 & \multirow{3}{*}{0,153} \\
\hline b. $\mathrm{SC}$ & 4 & 23,5 & 6 & 35,3 & 10 & 29,4 & \\
\hline Total & 17 & 100 & 17 & 100 & 34 & 100 & \\
\hline
\end{tabular}

Tabel 1 menunjukkan bahwa distribusi usia terbanyak adalah rentang usia 20-35 tahun sebanyak 25 orang $(73,5 \%)$, distribusi paritas responden multipara sebanyak 20 orang $(58,8$ $\%)$, tingkat pendidikan sebagian besar adalah SMA sebanyak 16 orang $(47,1 \%)$.
Sedangkan distribusi jenis persalinan terbanyak adalah normal dengan jumlah 24 orang $(70,6 \%)$. Hasil dari uji homogenitas karakteristik responden menunjukkan $p$ value $>\alpha(0,05)$ sehingga dapat disimpulkan varian data homogen. 


\section{Gambaran intensitas nyeri sebelum (pretest) dan sesudah (posttest) pada kelompok eksperimen dan kelompok kontrol}

Tabel 2

Rata-rata intensitas nyeri pembengkakan payudara pada kelompok eksperimen dan kelompok kontrol dalam dua hari

\begin{tabular}{lccccc}
\hline Intensitas nyeri & $\mathrm{n}$ & Rata-rata & SD & Min & Max \\
\hline Pre test & & & & & \\
Kelompok eksperimen & 17 & 5,7059 & 1,57181 & 3,00 & 8,00 \\
Kelompok kontrol & 17 & 5,0588 & 1,02899 & 3,00 & 7,00 \\
\hline Post test & & & & & \\
Kelompok eksperimen & 17 & 2,7059 & 0,98914 & 1,00 & 8,00 \\
Kelompok kontrol & 17 & 4,5294 & 1,17886 & 3,00 & 7,00 \\
\hline
\end{tabular}

Tabel 2 menunjukkan bahwa rata-rata intensitas nyeri pembengkakan payudara pretest kelompok eksperimen yaitu 5,7059 sedangkan rata-rata intensitas nyeri pre test pada kelompok kontrol yaitu 5,0588.

\section{A. Analisa Bivariat}

Proses pengolahan data dilakukan setelah dilakukan uji normalitas data menggunakan uji Shapiro-Wilk dan didapatkan hasil pre test $p$ value $(0,088)>\alpha$ $(0,05)$ dan post test $p$ value $(0,289)>\alpha(0,05)$,
Distribusi rata-rata intensitas nyeri post test kelompok eksperimen yaitu 2,7059 sedangkan rata-rata intensitas nyeri pembengkakan payudara post test pada kelompok kontrol yaitu 4,5294. maka disimpulkan bahwa kedua kelompok data terdistribusi normal, sehingga memenuhi syarat uji parametrik dependent sample t- test dan independent sample t-test.

\section{Uji homogenitas intensitas nyeri pembengkakan payudara pada kelompok eksperimen dan kelompok kontrol}

Tabel 3

Uji homogenitas intensitas nyeri pembengkakan payudara pada kelompok eksperimen dan kelompok kontrol

\begin{tabular}{llll}
\hline Kelompok & & $\mathrm{n}$ & P value \\
\hline \multirow{2}{*}{ Eksperimen } & Pre test & 17 & 0,204 \\
\cline { 2 - 4 } & Post test & 17 & 0,599 \\
\hline \multirow{2}{*}{ Kontrol } & Pre test & 17 & 0,193 \\
\cline { 2 - 4 } & Post test & 17 & 0,059 \\
\hline
\end{tabular}

Tabel 3 menunjukkan hasil uji homogenitas yang dilakukan dengan uji hipotesis Levene's test, didapatkan hasil $p$ value $>\alpha(0,05)$, sehingga disimpulkan bahwa varian data sama atau homogen. 
Ratih Indah Sari ${ }^{1}$, Yulia Irvani Dewi ${ }^{2}$, Ganis Indriati ${ }^{3}$, Efektivitas Kompres Aloe Vera terhadap Nyeri Pembengkakan Payudara pada Ibu Menyusui

\section{Perbedaaan intensitas nyeri pembengkakan payudara kelompok eksperimen pretest- posttest kompres aloe vera}

Tabel 4

Perbedaan intensitas nyeri pembengkakan payudara kelompok eksperimen pretest- posttest kompres aloe vera

\begin{tabular}{llllll}
\hline Variabel & $\mathrm{n}$ & Rata-rata & SD & $\begin{array}{l}\text { Perbedaan } \\
\text { Rata-rata }\end{array}$ & P value \\
\cline { 1 - 4 } Pre test & 17 & 5,7059 & 1,57181 & 3,00000 & 0,000 \\
\hline Post test & 17 & 2,7059 & 0,98914 & & \\
\hline
\end{tabular}

Tabel 4 menunjukkan bahwa rata-rata $(0,05)$ dapat disimpulkan bahwa terdapat intensitas nyeri pembengkakan payudara perbedaan intensitas nyeri pembengkakan sebelum intervensi adalah 5,7059, sedangkan payudara sebelum dan sesudah pemberian rata-rata intensitas nyeri setelah intervensi kompres aloe vera.

adalah 2,7059. Perbedaan rata-rata nyeri antara sebelum dan sesudah intervensi adalah 3,00000 dan diperoleh $p$ value $=0,000<\alpha$

3. Perbedaaan intensitas nyeri pembengkakan payudara pada kelompok kontrol pretestposttest tanpa kompres aloe vera

Tabel 5

Perbedaan intensitas nyeri pembengkakan payudara pada kelompok kontrol pretest-posttest tanpa kompres aloe vera

\begin{tabular}{llllll}
\hline Variabel & $\mathrm{n}$ & Rata-rata & $\mathrm{SD}$ & $\begin{array}{l}\text { Perbedaan } \\
\text { Rata-rata }\end{array}$ & P value \\
\hline Pre test & 17 & 5,0588 & 1,02899 & 0,52941 & 0,177 \\
\hline Post test & 17 & 4,5294 & 1,17886 & 0 \\
\hline
\end{tabular}

Tabel 5 menunjukkan bahwa rata-rata intensitas nyeri pembengkakan payudara sebelum tanpa intervensi adalah 5,0588, sedangkan rata-rata intensitas nyeri setelah tanpa intervensi adalah 4,5294. Perbedaan rata-rata nyeri sebelum dan sesudah tanpa intervensi sebesar 0,52941 dan diperoleh $p$ value $(0,177)>\alpha(0,05)$, disimpulkan bahwa tidak terdapat perbedaan intensitas nyeri pembengkakan payudara sebelum dan sesudah tanpa pemberian kompres aloe vera. 
Jurnal Ners Indonesia, Vol.10 No.1, September 2019

4. Perbedaaan intensitas nyeri pembengkakan payudara pada kelompok eksperimen setelah diberikan kompres aloe vera dan kelompok kontrol tanpa diberikan kompres aloe vera (post test)

Tabel 6

Perbedaan intensitas nyeri pembengkakan payudara pada kelompok eksperimen dan kelompok kontrol setelah diberikan kompres aloe vera (post test)

\begin{tabular}{|c|c|c|c|c|c|}
\hline Variabel & $\bar{n}$ & Rata-rata & $\overline{\text { SD }}$ & $\begin{array}{l}\text { Perbedaan } \\
\text { Rata-rata }\end{array}$ & P value \\
\hline Posttest Eksperimen & 17 & 2,7059 & 0,98914 & \multirow{2}{*}{$-1,82353$} & \multirow{2}{*}{0,000} \\
\hline Posttest Kontrol & 17 & 4,5294 & 1,17886 & & \\
\hline
\end{tabular}

Tabel 6 menunjukkan bahwa rata-rata intensitas nyeri pembengkakan payudara posttest pada kelompok eksperimen sebesar 2,7059, sedangkan rata-rata intensitas nyeri posttest pada kelompok kontrol yaitu sebesar 4,5294 dan perbedaan rata-rata post test antara kelompok eksperimen dan kontrol sebesar -1,82353. Hasil uji statistik menunjukkan $p$ value $(0,000)<\alpha(0,05)$ maka dapat disimpulkan bahwa ada pengaruh kompres aloe vera terhadap intensitas nyeri pembengkakan payudara.

\section{PEMBAHASAN}

\section{A. Usia}

Hasil penelitian mayoritas usia responden yaitu rentang usia 20-35 tahun sebanyak 25 orang $(73,5 \%)$. Hal ini dikarenakan seorang wanita pada rentang usia 20-35 tahun merupakan masa reproduksi yang aman untuk masa kehamilan dan persalinan (Prawirohardjo, 2014). Hasil penelitian ini didukung oleh penelitian Rutiani dan Fitriana (2016) bahwa usia ibu nifas berpengaruh terhadap kejadian pembengkakan payudara dan sebagian besar terjadi pada usia 20-35 tahun, akibat kurangnya pengalaman, pemahaman dan informasi tentang pembengkakan payudara.

Hasil penelitian juga menemukan bahwa terdapat usia $<20$ tahun $(5,9 \%)$ dan usia $>35$ tahun $(20,6 \%)$. Usia $<20$ tahun dianggap belum matang secara fisik, organorgan reproduksi belum berfungsi secara sempurna sehingga bila terjadi kehamilan dan persalinan akan lebih beresiko mengalami komplikasi, sedangkan untuk usia > 35 tahun dianggap berbahaya karena sudah terjadi penurunan kesehatan reproduktif akibat proses degeneratif, alat reproduksi dan fisik ibu sudah jauh berkurang dan menurun (Mubasyiroh, Tejayanti, \& Senewe, 2016).

\section{B. Paritas}

Hasil penelitian, paritas responden terbanyak adalah multipara sebanyak 20 orang $(58,8 \%)$. Hasil penelitian ini juga menemukan bahwa sebanyak 12 orang $(35,3 \%)$ ibu nifas dengan paritas pimipara mengalami pembengkakan payudara. Hal ini didukung oleh penelitian Rutiani dan Fitriana (2016) yaitu sebanyak 11 orang (57,9\%) ibu nifas dengan paritas primipara mengalami 
Ratih Indah Sari ${ }^{1}$, Yulia Irvani Dewi ${ }^{2}$, Ganis Indriati ${ }^{3}$, Efektivitas Kompres Aloe Vera terhadap Nyeri Pembengkakan Payudara pada Ibu Menyusui

pembengkakan payudara, dimana paritas primipara lebih berpeluang besar mengalami pembengkakan payudara akibat belum pernah memiliki pengalaman sebelumnya tentang melahirkan dan menyusui bayi.

Peneliti berasumsi bahwa status paritas tidak dapat dijadikan sebagai pedoman bahwa hanya paritas primipara yang berpeluang mengalami nyeri pembengkakan payudara. Paritas multipara juga mengalami pembengkakan payudara. Hal ini terjadi karena banyaknya faktor pencetus seperti frekuensi menyusui, masalah pada puting, isapan bayi yang tidak kuat, ataupun posisi menyusui yang salah sehingga ASI terkumpul dan tidak dikeluarkan sehingga nyeri pembengkakan semakin meningkat.

\section{Pendidikan terakhir}

Hasil penelitian menemukan bahwa mayoritas pendidikan responden adalah SMA sebanyak 16 orang $(47,1 \%)$. Yanti (2017) juga menemukan hal yang sama bahwa responden menyusui yang mengalami pembengkakan payudara mayoritas berpendidikan SMA (43,3\%).

Rutiani dan Fitriana (2016) menyatakan bahwa tingginya tingkat pendidikan berpengaruh terhadap kejadian pembengkakan payudara, seseorang dengan tingkat pendidikan tinggi akan lebih banyak mengetahui informasi, memiliki wawasan yang luas, daya tangkap dan pola pikir yang jauh lebih baik, sehingga mempunyai peluang lebih untuk mengetahui informasi tentang pembengkakan payudara dan cara mengatasi pembengkakan payudara, akan tetapi tingkat pendidikan seseorang tidak dapat dijadikan pedoman bahwa sesorang akan berhasil pada proses menyusui. Hal ini sejalan dengan penelitian Sutrisno (2015) menunjukkan bahwa ibu memiliki sikap rendah dalam proses menyusui namun tingkat pendidikannya tinggi, dan sebaliknya ibu berpendidikan rendah namun memilki sikap yang tinggi dalam proses menyusui.

\section{Jenis Persalinan}

Hasil penelitian menunjukkan bahwa mayoritas jenis persalinan responden adalah normal sebanyak 24 orang (70,6\%). Hasil penelitian ini sejalan dengan penelitian Sharma (2018) dimana mayoritas ibu yang mengalami pembengkakan payudara dengan jenis persalinan normal sebanyak (64\%) pada kelompok eksperimen dan sebanyak $(66,6 \%)$ pada kelompok kontrol.

Hasil penelitian ini juga menemukan sebanyak 10 orang $(29,4 \%)$ dengan jenis persalinan sectio caesarea. Wijaya (2018) menyatakan bahwa ibu dengan post sectio caesarea tidak mulai menyusui bayinya pada hari pertama melahirkan seharusnya 24 jam setelah melahirkan merupakan masa yang penting untuk proses inisiasi pemberian ASI yang akan menentukan keberhasilan menyusui selanjutnya. Jika ibu tidak menyusui akibatnya bayi diberikan susu formula untuk mengganti kebutuhan ASI. 
Jurnal Ners Indonesia, Vol.10 No.1, September 2019

Hal ini sejalan dengan penelitian Dewi (2016) menyatakan bahwa ibu dengan post sectio caesarea lebih memilih pasif dan beristirahat dibandingkan memberikan ASI kepada bayinya walaupun ibu tahu bahwa ASI merupakan makanan terbaik bagi bayi, sehingga kondisi inilah yang dapat menyebabkan bengkak dan nyeri payudara semakin meningkat. Peneliti berasumsi bahwa baik jenis persalinan normal dan sectio caesarea dapat mengalami pembengkakan payudara.

E. Perbedaan rata-rata intensitas nyeri pembengkakan payudara pada kelompok kontrol dan eksperimen

Hasil penelitian didapatkan rata-rata nyeri pada kelompok eksperimen adalah 5,7059 setelah diberikan intervensi menjadi 2,7059 dan perbedaan nyeri 3,00000 dengan $p$ value $(0,000)<\alpha(0,05)$. Sedangkan pada kelompok kontrol adalah 5,0588 setelah tanpa intervensi intensitas nyeri menjadi 4,5294. Perbedaan intensitas nyeri 0,52941 dengan $p$ value $(0,177)>\alpha(0,05)$, dapat disimpulkan bahwa terjadi penurunan intensitas nyeri pembengkakan payudara pada kelompok eksperimen, sedangkan pada kelompok kontrol tidak terdapat perbedaan intensitas nyeri sebelum dan sesudah tanpa intervensi.

Peneliti berasumsi bahwa pada kelompok eksperimen terdapat penurunan intensitas nyeri yaitu nyeri sedang menjadi nyeri ringan, sedangkan pada kelompok kontrol intensitas nyeri tetap berada dalam kategori nyeri sedang. Hal ini terjadi karena beberapa hal yang dapat mempengaruhi intensitas nyeri pembengkakan payudara seperti isapan bayi, masalah pada puting, kesalahan posisi, ASI yang tidak dikosongkan secara sempurna, produksi ASI yang berlebihan sementara kebutuhan bayi pada hari-hari pertama setelah melahirkan masih sedikit, pengeluaran ASI yang jarang, dan waktu menyusui yang terbatas (Walyani \& Purwoastuti, 2015).

Peneliti juga berasumsi bahwa intensitas nyeri dapat dipengaruhi oleh frekuensi menyusui, jika ibu tidak sering memberikan ASI maka payudara semakin membengkak dan nyeri yang dirasakan semakin meningkat karena ASI tidak lancar. Proses menyusui juga akan terhambat karena ibu merasa nyeri pembengkakan payudara, sehingga ibu takut ataupun malas untuk menyusui (Nurhayati \& Suratni, 2017). Hal ini dapat mempengaruhi intensitas nyeri pembengkakan payudara yang dirasakan ibu menyusui.

\section{F. Efektivitas kompres aloe vera terhadap nyeri pembengkakan payudara}

Hasil analisis didapatkan rata-rata intensitas nyeri pembengkakan payudara pada kedua kelompok adalah $p$ value $(0,000)<\alpha$ $(0,05)$, sehingga disimpulkan kompres aloe vera efektif terhadap nyeri pembengkakan payudara. Aloe vera banyak mengandung air dan berbagai zat yang dapat mengurangi nyeri sehingga nyeri yang dirasakan akan berkurang. Aloe vera mengandung anthraquinone, aloe emodin, enzim bradikinase, carboxypeptidase, salisilat, 
Ratih Indah Sari ${ }^{1}$, Yulia Irvani Dewi ${ }^{2}$, Ganis Indriati ${ }^{3}$, Efektivitas Kompres Aloe Vera terhadap Nyeri Pembengkakan Payudara pada Ibu Menyusui

tannin dan saponin yang masing-masing memiliki kemampuan sebagai anti nyeri dan anti inflamasi (Tim Agro Mandiri, 2016). Hariana (2015) menyatakan bahwa aloe vera bersifat dingin dan mengandung zat lignin yang memiliki kemampuan penyerapan yang tinggi. Efek dingin pada aloe vera dapat meningkatkan kenyamanan pada ibu yang mengalami nyeri pembengkakan.

Setelah post partum terjadi perubahan hormon laktasi yaitu oksitosin dan prolaktin yang masing-masing memiliki tugas untuk produksi ASI dan pengeluaran ASI, namun kerjanya dipengaruhi oleh isapan bayi. Isapan bayi yang tidak adekuat merupakan salah satu faktor yang menyebabkan pembengkakan payudara. Pembengkakan payudara terjadi karena adanya peningkatan aliran darah vena dan limfe serta penyempitan pada duktus laktiferus akibat ASI yang terkumpul didalam payudara. Hal ini dapat mengakibatkan timbulnya rasa nyeri, selain itu rasa nyeri yang timbul juga dapat diakibatkan karena peregangan pada jaringan mammae akibat pembengkakan yang terjadi sehingga menekan reseptor nyeri (Wahyuni, 2018). Ketika terjadi nyeri maka akan terjadi pelepasan neurotransmitter nyeri salah satunya prostaglandin (Potter \& Perry, 2010). Kompres aloe vera dapat menurunkan nyeri pembengkakan dengan cara merangsang sistem kekebalan tubuh untuk memblokir biosintesis prostaglandin (Akbar \& Rizky, 2015).

Hasil penelitian Sushen et al (2017) menjelaskan bahwa aloe vera dapat digunakan untuk mengatasi nyeri payudara akibat menstruasi, nyeri tumor payudara atau akibat pemberhentian ASI. Selain itu aloe vera dapat digunakan untuk nyeri sendi, arthritis, dan nyeri otot. Hasil penelitian lainnya dilakukan oleh Hasanah, Novayelinda, Maifera dan Isdelni (2017) tentang penggunaan kompres aloe vera untuk mengatasi flebitis dan didapatkan hasil $p$ value $(0,000)<\alpha(0,05)$ disimpulkan bahwa setelah mendapatkan kompres aloe vera derajat flebitis menjadi derajat 1 tanpa nyeri dan pembengkakan.

\section{SIMPULAN}

Hasil penelitian dapat disimpulkan bahwa mayoritas responden berusia 20-35 tahun dengan paritas multipara, memiliki latar belakang pendidikan SMA dan jenis persalinan normaL. Hasil analisa statistik didapatkan bahwa kompres aloe vera efektif terhadap nyeri pembengkakan payudara pada ibu menyusui dengan $p$ value $(0,000)<\alpha$ $(0,05)$. 


\section{SARAN}

1. Bagi perkembangan ilmu keperawatan

Kompres aloe vera dapat dijadikan sebagai sumber informasi dan bahan pembelajaran pemanfaatan terapi komplementer dan TOGA untuk menangani masalah nyeri pembengkakan payudara di mata kuliah keperawatan maternitas dan pemanfaatan aloe vera untuk mengatasi nyeri lainnya.

2. Bagi masyarakat/ibu

Terapi ini dapat dijadikan terapi non farmakologis untuk mengurangi nyeri pembengkakan payudara secara efisien dan efektif.

3. Bagi penelitian berikutnya

Perlu dilakukan penelitian lebih lanjut untuk perbandingan dan mengkaji karakteristik responden tentang perawatan payudara, pengalaman menyusui, pekerjaan, dan lain-lain.

\section{DAFTAR PUSTAKA}

Afriani., \& Amin, W. (2018). Pengetahuan dan sikap ibu menyusui dengan pemberian ASI secara on demand di RSB. Restu Makassar. Media Kesehatan Politeknik Kesehatan Makassar, 13(2), 14-18. Diperoleh pada tanggal 22 Mei 2019 dari https://doi.org/10.32382/ medkes.v13i2.525.

Akbar N. H., \& Rizki, M. I. (2015). Potential analgesic agents and action mechanism of phytochemicals from Indonesia natural products- a review. Proceedings of International Conference on NAMES. Diakses pada tanggal 03 Februari 2019 dari

https://www.researchgate.net/publicatio $\mathrm{n} / 309134139$.

Alhadar, F., \& Umaternate, I. (2017).
Pengaruh perawatan payudara pada ibu hamil terhadap peningkatan produksi ASI di wilayah kerja puskesmas kota kecamatan kota Ternate Tengan tahun 2016. Jurnal Riset Kesehatan, 6(1), 7 12. Diperoleh pada tanggal 03 Februari 2019 dari https://www.researchgatenet/ publication/327054399.

Apriani, A., Wijayanti., \&Widyastutik, D. (2018). Efektivitas penatalaksanaan kompres daun kubis (brassica oleracea var.capita) dan breast care terhadap pembengkakan payudara bagi ibu nifas. Maternal, 2(4), 238-243. Diperoleh pada tanggal 08 Desember 2018 dari https://ejurnal.stikesmhk.ac.id.

Dewi, U. M. (2016). Faktor yang mempengaruhi praktik menyusui pada ibu post section caesarea di RSI A. Yani Surabaya. Jurnal Ilmiah Kesehatan, 9(1), 43-47. Diperoleh pada tanggal 19 Juni 2019 dari http://journal.unusa.ac.id/ index.php/jhs/article/view/83/75.

Hariana, A. (2015). Tumbuhan obat dan khasiatnya. Jakarta: Penebar Swadaya.

Hasanah, O., Novayelinda, R., Maifera., \& Isdelni. (2017). Menurunkan derajat flebitis akibat terapi intravena pada anak dengan kompres aloe vera: studi pilot. Jurnal Keperawatan Indonesia, 20(1), 24-31. Diperoleh pada tanggal 03 Februari 2019 dari https:// www.researchgate.net/publication/3183 43957.

Indahsari, M. N., \& Chotimah, C. (2017). Hubungan tingkat pengetahuan ibu nifas tentang perawatan payudara perawatan payudara dengan kejadian bendungan asi di RB Suko Asih Sukoharjo. Indonesian Journal On Medical Science, 4(2), 183-188. Diperoleh pada tanggal 08 Desember 2018 dari http://ejournal.ijmsbm.org/index.php/ij $\mathrm{ms} /$ article/view/116.

John, L., Cordeiro, M. P., MG, Manjima., Gopinath, R., \& Tamrakar, A. (2015). Knowledge regarding breast problems among antenatal mothers in a selected hospital, Mangaluru with view to develop an information booklet. International Journal of Recent Scientific Research, 6(9), 6228-6231. 
Ratih Indah Sari ${ }^{1}$, Yulia Irvani Dewi ${ }^{2}$, Ganis Indriati ${ }^{3}$, Efektivitas Kompres Aloe Vera terhadap Nyeri Pembengkakan Payudara pada Ibu Menyusui

Diperoleh pada tanggal 08 Januari 2019 dari http://www.recentscientific.com/ sites/default/files/3413.pdf

Manna, M., Podder, L., \& Devi, S. (2016). Effectiveness of hot fomentation versus cold compression on breast engorgement among postnatal mothers. International Journal of Nursing Research and Practice, 3(1), 13-18. Diperoleh pada tanggal 12 Januari 2019 dari https://www.researchgate.net/ publication/312552225.

Meihartati, T. (2017). Hubungan antara perawatan payudara dengan kejadian bendungan ASI (engorgement) pada ibu nifas. Jurnal Kebidanan dan Keperawatan, 13(1), 19-24. Diperoleh pada tanggal 12 Januari 2019 dari https://www.researchgate.net/publicatio $\mathrm{n} / 324116366$.

Mubasyiroh, R., Tejayanti, T., \& Senewe, F. P. (2016). Hubungan kematangan reproduksi dan usia saat melahirkan dengan kejadian bayi berat lahir rendah (BBLR) di Indonesia tahun 2010. Jurnal Kesehatan Reproduksi, 7(2), 109-118. Diperoleh pada tanggal 24 Mei 2019 dari http://media.neliti.com/media/ publication/107918.

Mwale, M., \& Masika, P. J. (2010). Analgesic and anti-imflammatory activities of aloe ferox mill aqueous extract. African Journal of Pharmacy and Pharmacology, 4(6), 291-297. Diperoleh pada tanggal 22 Februari 2019 dari https://www.researchgate.net/ publication/228624791.

Potter, P. A., \& Perry, A. G. (2010). Fundamental of nursing. Singapore: Elsivier Inc.

Prawirohardjo, S. (2014). Ilmu kandungan. Edisi 3. Jakarta: PT Bina Pustaka Sarwono Prawirohardjo.

Riskesdas. (2018). Hasil utama riskesdas. Badan Penelitian dan Pengembangan Kesehatan, Kementerian Kesehatan RI.

Rosyati, H., \& Sari, W. A. (2016). Pengetahuan ibu nifas tentang perawatan payudara di Puskesmas Kecamatan Pulo Gadung Jakarta Timur tahun 2016. Jurnal Kedokteran dan Kesehatan, 12(2), 137-143. Diperoleh pada tanggal 12 Februari 2019 dari https://jurnal.umj.ac.id.

Rutiani, C.E.A., \& Fitriana, L.A. (2016). Gambaran bendungan ASI pada ibu nifas dengan seksio sesarea berdasarkan karakteristik di rumah sakit Sariningsih Bandung. Jurnal Keperawatan Indonesia, (2), 146-155. Diakses pada tanggal 11 Januari 2019 dari https://www..researchgate.net/publicatio $\mathrm{n} / 322760075$.

Sharma, R. (2018). Effectiveness of chilled cabbage leaf application on breast engorgement among postpartum women's. Journal Of Medical Science And Clinical Research, 6(6), 878-882. Diperoleh pada tanggal 12 Januari 2019 dari https://www.researchgate.net/ publication $/ 326016557$.

Surya, P., Gouri, B., Yogeshchand, R., Gyanander, A., Jitender, B., \& Garg, B. (2015). Aloevera; a natural adjunct in periodontal therapy. International Journal of Research and Development Organization, 1(9), 1-12. Diperoleh pada tanggal 12 Februari 2019 dari https://slidex.tips/download/aloevera-anatural-adjunct-in-periodental-therapy.

Sushen, U., Unnithan, C. R., Rajan, S., Chouhan, R., Chouhan, S., Uddin, F., \& Kowsalya, R. (2017). Aloe vera a potential herb used as traditional medicine by tribal people of Kondagatu and Purudu of Karimnagar district, Telanga state, India, and their preparative methods. European Journal of Pharmaceutical and Medical Research, 4(7), 820-831. Diperoleh pada tanggal 22 November 2018 dari www.ejmpr.com.

Sutrisno. (2015). Hubungan tingkat pendidikan ibu dengan sikap pemberian ASI eksklusif di wilayah Puskesmas Kartasura Kabupaten Sukoharjo. Naskah Publikasi. Diperoleh pada tanggal 22 Mei 2019 dari https://eprints.ums.ac.id/39485/12. 
Thomas, A. A., Chhugani, M., \& Thokchom, S. (2017). A quasi-experimental study to assess the effectiveness of chilled cabbage leaves on breast engorgement among postnatal mothers admitted in a selected hospital of Delhi. Int J Nurs Midwif Res, 4(1), 8-13. Diperoleh pada tanggal 12 Januari 2018 dari https://www.researchgate.net/publicatio $\mathrm{n} / 31747716$.

Tim Agro Mandiri. (2016). Agrobisnis budi daya lidah buaya. Surakarta: Visi Mandiri.

UNICEF., \& WHO. (2018). Capture the moment-early initiation of breastfeeding: Newborn. New York: UNICEF.

Wahyuni, E. D. (2018). Asuhan kebidanan nifas dan menyusui. Jakarta: Pusdik SDM Kesehatan.

Walyani, E.S., \& Purwoastuti, E. (2015). Asuhan kebidanan masa nifas dan menyusui. Yogyakarta: Pustaka baru Press.

Wijaya, P. W. D. (2018). Faktor-faktor yang berpengaruh terhadap perilaku pemberian ASI eksklusif. Naskah Publikasi. Diperoleh pada tanggal 20 Juni 2019 dari http://eprints.ums.ac.id.

Yanti, D., \& Sundawati, D. (2011). Asuhan kebidanan masa nifas belajar menjadi bidan profesional. Bandung: PT Refika Aditama.

Yanti, P. D. (2017). Hubungan pengetahuan, sikap ibu dengan bendungan ASI di Puskesmas Sidomulyo Pekanbaru. Journal Endurance, 2(1), 81-88. Diakses pada tanggal 22 November 2018 dari http://ejournal.kopertis10. or.id/index.php/endurance/article/view/1 675.

Zuhana, N. (2017). Perbedaan efektifitas daun kubis dingin (brassica oleracea var. capita) dengan perawatan payudara dalam mengurangi pembengkakan payudara (breast engorgement) di kabupaten Pekalongan. Jurnal Ilmiah Bidan, 2(2), 51-56. Diperoleh pada tanggal 22 November 2018 dari https://ejournal.ibi.or.id/index.php/jib/ar ticle/view/34. 